Alla V. Demianiuk ${ }^{1}$, senior lecturer of Department of hydro construction and hydraulics

Dmytro V. Stefanyshyn ${ }^{1,2}$, Doctor of sciences (Eng.), Lead researcher of the Department of natural resources of the Institute of Telecommunications and Global Information Space of the NASU, associate professor, professor of the Department of hydro construction and hydraulics of the National University of Water and Environmental Engineering

ORCID ID: 0000-0002-7620-1613 e-mail: d.v.stefanyshyn@nuwm.edu.ua

${ }^{1}$ The National University of Water and Environmental Engineering, Rivne, Ukraine

${ }^{2}$ Institute of Telecommunication and Global Information Space of NASU, Kyiv, Ukraine

\title{
IDENTIFICATION OF EARTHEN DAM SEEPAGE REGIME UNDER CONDITION OF DATA AMBIGUITY
}

\begin{abstract}
One case of seepage regime identification in earthen dam on the basis of visual and instrumental observations is considered in terms of data ambiguity and uncertainty regarding either dam condition, soils permeability or seepage control and drainage features operability both in dam body and foundation. The technique of identification of dam fill hydraulic conductivity based on correlation analysis of piezometric readings is proposed. Contour maps of groundwater levels were examined. As well as simulation modelling was performed in order to determine the most probable seepage computational model of earth dam corresponding in the best way to monitoring data. While simulating special attention was being payed to seepage control and drainage features performance. Thus it was approved that earth dam seepage regime meets the criteria of safety against seepage.

Keywords: ambiguity and uncertainty; earthen dam; identification; imperfect information; observational data; seepage; seepage regime; seepage computational model; simulation modelling
\end{abstract}

\section{Introduction}

Seepage through earthen dam body and foundation determines its operational condition considerably. Seepage can initiate a number of adverse processes that affect negatively on structure condition.

Seepage generates volume hydrodynamic forces in dam fill and foundation which are comparable to soil weight [1]. Those forces affect adversely stability of dam slopes and may result in seepage induced deformations of different types (mechanical and chemical suffusion, heave, clogging etc.) [20]. Seepage is found out to be one of the main causes of malfunctioning, deterioration and failures of earthen dams.

Statistical analysis of causes of earthen dam failures makes it clear that the major part of dam collapses (up to 60\%) directly or indirectly was caused by detrimental impact of seepage $[2,3,19,20]$. Other seepage related accidents have also been registered like those ones when normal dam operation was impossible due to inability to fill reservoir lake to operation levels or water logging of vast terrain beneath the dam having devastating consequences for environment and population of those areas [4].

(C) A.V. Demianiuk, D.V. Stefanyshyn, 2019 
Adverse effects of seepage on earth dam condition can appear not only during first years of operation but also in the long run, after decades of "normal" operation $[3,5-7,19,20]$. According to statistics, one fifth of all collapses of earthen dams happened fifty years after their commissioning. The case of earth dam failure caused by seepage related problems after 116 years of operation (dam Emery, USA [8]) was documented.

The problem of seepage through soil porous medium including earthen dams is being studied for a long time [2, 9-11]. Currently there are a large number of differently posed seepage related problems having different levels of complexity. And thus there are many tried-and-tested techniques of their solving. Since then scientists also began to pay big attention to practical use seepage problems regarding to identification of computational models and dam condition estimation with the use of monitoring data [12-17].

However, the problem of seepage through earthen dams still remains the most relevant one. It is expected, it will be the same in the future, because most of water retaining structures in the world and Ukraine as well are earthen dams. The major part of them is in operation for a long time. As experience proves [18] due to ageing of dams that implies changing of structure condition, soil characteristics, reduced operability of seepage control and drainage features etc. the topic of the research can gain even more relevance with time.

\section{Some general notes}

Seepage regime (or seepage situation) in earth dam depends on many factors. Seepage can be examined with monitoring of phreatic surface position, head losses or gradients in dam fill and foundation, impervious elements and drainage facilities, zones of seepage flow exit in foundation and abutments (at river valley sides and concrete structures). It also can be examined through the measurements of seepage quantities collected from particular dam sections and total seepage amount collected from entire structure. Seepage regime monitoring can be performed as manually as by means automated systems for both instrumentation and visual observations. Nowadays, instrumental monitoring of seepage through earthen dam is based on piezometric levels and seepage amounts measurements.

In respect of earth dams reliability and safety seepage regime can be determined either allowable or unallowable. When proper arrangements are made allowable seepage regimes may be considered as safe. On the contrary, unallowable regimes are always hazardous for structure operation [9]. When designing a dam, only allowable seepage regimes are considered as design cases. Typically those are steady seepage flow defined with specified constant boundary conditions as well as nonsteady seepage flow appearing due to either non-stationary conditions on seepage boundaries or changing of soil voids volume (like in the case of clay soils consolidation) [9].

For earthen dams under operation seepage regime can vary at different time periods. Some seepage regimes can happen to be unallowable ones that under certain circumstances may lead to disaster. One of the most hazardous unallowable seepage regime in earthen dams is piping $[1,6-8,20]$, when in some reason, for instance, due to various defects such as insufficient soil compaction, cracking caused by differential settlement, animal burrowing, concentrated seepage flow appears. Piping 
is characterized with high flow velocities and gradients that can end up in either deterioration or collapse of dam body or foundation.

In many cases, unallowable seepage regimes, unlike allowable ones that are design load cases, cannot be determined unambiguously. They can appear both spontaneously, due to internal processes, and in a random way when caused by various external factors. Most of external factors, a priori, are uncertain and their influence on dam condition is ambiguous.

\section{Case study}

The earthen homogeneous hydraulic fill-type dam with maximum height $17.5 \mathrm{~m}$ and $500 \mathrm{~m}$ long is examined. Maximum head is $14.0 \mathrm{~m}$. The dam is located on the floodplain of the Dnipro River. The upstream slope is faced with reinforced concrete $20 \mathrm{sm}$ thick slabs. On the downstream side of the dam toe drain with stone pitching having total thickness $0.5 \mathrm{~m}$ (including $0.2 \mathrm{~m}$ thick riprap) was provided. V-ditch drain with average depth $0.6 \mathrm{~m}$ collects seepage water.

For the most part of its length the dam rests on stratified soils (about $10 \mathrm{~m}$ thick) including permeable alluvial sands underlain with tight silty sand stratum that is the local confining bed. The interface of dam body with bedrock foundation is the most complex section of the structure. That is a boundary between two strata with different geological origins: limestone and sedimentary sands. Limestone is highly karstified with filling of karst caverns with sandy and muddy deposits. That stratum is characterized with strong anisotropy of its permeability. Hydraulic conductivity of the stratum ranges from 1 to $400 \mathrm{~m}$ per day.

Due to complex geology several seepage control devices were employed such as impervious blanket over the contact surface of sandy soil and limestone and two grout curtains. On the terrain behind the dam there are also relief wells draining limestones in the dam foundation.

From the beginning of the dam operation seepage monitoring have been provided including piezometric levels and seepage quantities measurements. About 10 years ago the dam was equipped with automated monitoring system (AMS). By means AMS piezometric measurements are performed with hourly frequency. But as AMS operation isn't tuned perfectly piezometric levels time series comprise numerous suspected readings. Therefore, there is a doubt about data acquisition continuity and consistency. There are quite long gaps in time series that contributes to increasing complexity of the problem of piezometric levels behavior analysis. Along with automated control manual piezometric measurements are performed but with lower frequency (once or twice per month). In general, despite manually measured piezometric levels are more trustworthy, obtained datasets of piezometric readings are found to be incomplete.

Currently measurements of seepage flow quantities are performed in a manual way only. Cipolletti weir installed in the drain ditch is used for flow control. Measurements are performed with frequency once per month.

For a long time within downstream shoulder of $50 \mathrm{~m}$ long dam section near the left bank high elevations of phreatic surface are registered by piezometric grid. Periodically phreatic surface emerging on the slope occurs. There are also visual signs of high position of ground water on this area such as water saturation of soils in toe zone (actually, signs of waterlogging) and heavy grass greening. In winter time in the case of severe frosts freezing of toe drain as well as piezometers in near- 
drainage area was detected. All those processes are observed periodically but from the very beginning of dam operation, actually from the first impoundment. Simultaneously, seepage discharges reduction is observed with consistent declining trend in measured seepage quantities collected with drainage ditch. For instance, during the period from the end of $1950^{\text {th }}$ to 1992 average seepage quantity has decreased by nearly 7 times. Reduction of seepage quantities is being observed in the following years till nowadays.

All above-mentioned effects, processes, circumstances and tendencies can be interpreted as ambiguous ones. They are unless harmful, then unwanted at least. In general, according to all those signs it can be definitely said merely that the seepage regime in the dam section is quite complex and it needs to be analyzed. But it would be wrong to conclude decisively whether the regime is allowable or unallowable until the causes of observed effects and phenomena as well as conditions under which those processes can turn into endangering ones are determined.

\section{Objective and tasks}

The causes of poor seepage performance of earthen dams may be different. Unallowable seepage situation may arise gradually, for instance, due to changes of soils permeability following with stratification or hydraulic conductivity anisotropy. Those changes can be caused by long-term developing of internal erosion within some sections and clogging within others. As well as due to freezing of downstream dam shoulder kind of confined seepage flow may occur. Enhanced infiltration resulting from torrential precipitation or rapid snow melting when snow falls on nonfrozen dam slope may have adverse effect on seepage regime too.

Construction errors and violation of operation rules can also affect negatively dam seepage regime. In each instance these may be the most various causes, conditions and circumstances resulting in seepage situation that could become endangering for dam condition. Some effects and processes determining newly formed seepage regime can be long-lasting that still keep developing, others can be comparatively short-lasting but periodically appearing.

Among the factors that might complicate seepage performance significantly are as follows: complex geology of foundation and river valley sides, malfunctioning of seepage control or drainage features, inadequately employed types of seepage control measures, interaction of seepage flow through dam body and foundation with other structures including concrete ones.

In order to estimate the influence of seepage on the current dam condition it's essential to identify actual seepage regime in terms of its allowability. It must be also taken into account that data of instrumental measurements (piezometric levels and seepage amounts) are imperfect. Data series may contain readings that are of concern (so called suspected readings). The same can refer to uncertainty, ambiguity and fuzziness of engineering and geophysical surveys data, field and laboratory testing data of conductivity of soils in dam body and foundation, that, may happen, do not reflect the actual situation because soil properties have been changed.

Consequently, there is a need to identify the real seepage computational model of earthen dam with regard to those changes as well as actual condition of seepage control and drainage devices. It's also crucial to determine causes of unwanted effects observed and to reveal the conditions and circumstances under what seepage may be judged as unallowable for the dam. 
Accordingly, the main task of the research was set as identification of the current seepage regime and its estimation in terms of its allowability. The task of determining the causes of unwanted effects is also posed. The objective of this paper is to present approaches and techniques that can be employed for seepage regime identification amidst imperfect information that implies lack of information, data uncertainty, ambiguity and different kinds of fuzziness.

\section{Methodology and results}

\subsection{Some general considerations in regards to the problem of identification of mathematical model of seepage in earthen dam}

Earthen dams are complex dynamic systems. Dam condition keeps changing continuously and seepage is one of the main causes of the changes [7, 8, 14, 17, 20, 21]. Therefore different mathematical seepage models may correspond to certain periods of earth dam operation.

Operational particularities and load conditions, system configuration and input variables used for development of mathematical model of existing earthen dam may be not fully adequate to corresponding design values. In fact they are only partially determined. Perhaps, dam geometry and variables characterizing long-term external loads outlined in design requirements and operation regulations can be considered as well-defined parameters.

Such input variables and factors as general operational particularities, real configuration and true condition of seepage control and drainage features as well as permeability characteristics of individual layers of dam fill and foundation are still not specified or weak-defined. All those factors and parameters that determine current dam operational particularities, real system entities and parameters (coefficients) of dam seepage computational model are needed to be additionally evaluated or revised according to the real situation [14-16, 21].

Evaluation or redetermination of operational particularities, real system configuration and parameters (coefficients) in order to refine computational model with the use of performance data obtained through field investigations or laboratory tests is conventionally termed as identification of the system model. In this case model to be identified is exactly the model that will be used for direct structure analysis for the purpose of estimation of current structure condition and forecasting of its behavior.

The problem of computational (numerical, mathematical) model identification of system, structure, process, effect etc. is so called inverse problem that is referred to ill-posed problems [22]. The salient feature of that kind problems is solution instability or uncertainty. It means multiple valid solutions exist when different operational particularities, system entities and model parameters (coefficients) may correspond to same inputs (observational data). In order to simplify the problem of identification of seepage regime in earthen dam it's suggested to decompose it. Following the approach of L. Ljung [23] therefore several separated problems can be solved sequentially: the problem of operational particularities identification and the problem of system's structure and parameters identification. According to the approach, to solve the problem of identification of complex system model it isn't always necessary to follow strict mathematical methods. It's important to draw on implicit information that data sets contain. To set nonstandard requirements to the 
model basing on a priori knowledge about the object studied and with respect to the purpose of modelling can be useful too.

\subsection{Identification of dam operational particularities}

For more detailed analysis of the seepage situation possible three-dimensional effects in seepage flow pattern should be estimated.

The earthen dam studied has sufficient length $(500 \mathrm{~m})$ but it abuts upon parent rock having complex geology on its left side and concrete structure (ship lock) on its right side. Hence influence of adjacent structures and geological features on general seepage flow pattern and notably on seepage flow exit conditions can't be excluded.

To examine the spatial pattern of seepage flow through dam body graphical techniques were employed such as contour map of groundwater level constructing based on piezometric readings [2].

Several ground water flow maps were plotted for typical observed cases of phreatic surface position registered by piezometric grid on various dates referred to different seasons and different years of dam operation. An example of groundwater contour map for one of the cases considered is given in fig. 1 .

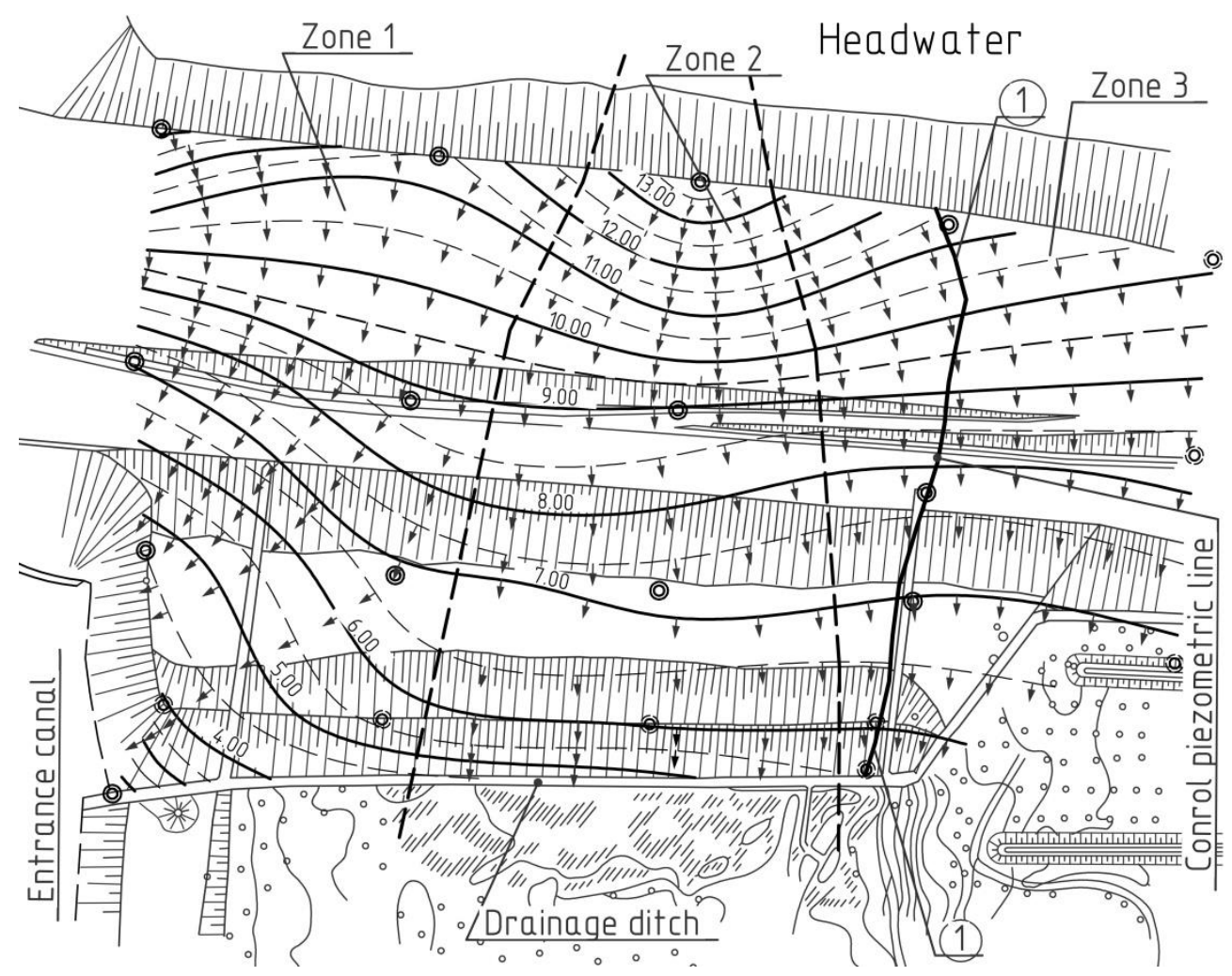

Fig. 1 - An example of the contour map of groundwater levels observed in the earthen dam body

Generally, within obtained groundwater contour maps three specific zones can be revealed that differ in flow lines directions as follows: 
- Zone \#1 having curvilinear shaped stream lines with free subaqueous exit of seepage flow under tailwaters table;

- Zone \#2 with parallel linear-like evenly spaced stream lines in near exit section;

- Zone \#3 with curved stream lines crowded with stream lines partially directed from zone \#2 and from the seepage flow through rock abutment.

Similarly shaped contour maps characterized with three defined specific zones were obtained for all operational cases considered regardless to year and season. But bearing in mind area topography in the dam site, dam abutting upon bedding rock and ship lock, seepage pattern with stream lines bended towards the tail race canal within all three zones of earthen dam body would be more appropriate to the situation under condition of drainage facilities efficient performance.

According to seepage net pattern obtained (fig. 1) it can be assumed that seepage flow concentrated within zone 2 complicates seepage water exit conditions in zone 3 . That is exactly the dam section where abnormal seepage regime is observed and signs of slope deterioration were found out. Merge of differently directed seepage flows within examined dam section results in seepage waters being concentrated in a small area. To summarize, dam seepage regime shows tangible three-dimensional effects. Hereafter, when separately considered, seepage regime in zone 3 can be assumed as two-dimensional but complicated by zone 2 flow exit conditions.

In such cases to judge whether current seepage regime is allowable or unallowable it's indispensable to estimate operability of seepage control and drainage features since they intended to reduce seepage flow and its detrimental influence to dam fill. Besides, those facilities are among the main structural elements of earthen dam that determine its seepage computational model.

\subsection{Seepage computational model identification}

Simulation modelling is one of the most efficient techniques of structural-parametric identification of models of complex systems that earthen dams are [7, 8, 14, 17, 20, 21].

For seepage model identification typically soil properties are the parameters to vary [21] such as hydraulic conductivity of dam fill and foundation strata $[15,16]$. When modelling an existing structure that has performance data calibrating the seepage model to measured performance is employed that implies varying (simulating) of model parameters until the modeled behavior closely approximates the measured behavior (piezometric levels and seepage amounts).

While calibrating the model, system entities can also be varied. In order to do that different seepage models e.g. hydraulic type schemes can be used as separated simulations [14]. It is assumed that structure while in operation can experience structural changes due to either suffusion or clogging developing in certain zones or malfunctioning of its structural elements (primarily seepage control and drainage features).

Notably that it's quite enough to identify hydraulic conductivity of the only layer which piezometers installed in (in the case studied that's the dam fill) and starting out from it instead of varying permeability of each stratum it's reasonable to simulate the ratio between already identified hydraulic conductivity value and permeability of other layers [14]. 


\subsubsection{Hydraulic conductivity value identification}

The following mathematical model of two-dimensional steady seepage flow can be used for identification of hydraulic conductivity of dam fill along control piezometric line (fig. 1) on the basis of piezometric readings taken at different timepoints:

$$
\begin{gathered}
\frac{\partial}{\partial x}\left(k_{\mathrm{c}} \frac{\partial H}{\partial x}\right)=\frac{\partial H}{\partial t} ; H(x, 0)=H_{0}(x), 0 \leq x \leq l ; \\
H(0, t)=H_{1}(t), 0 \leq t \leq t_{1} ; H(l, t)=H_{2}(t), 0 \leq t \leq t_{1},
\end{gathered}
$$

where $k_{c}$ is hydraulic conductivity; $H(x, t)$ is hydraulic head at a point $x$ in seepage domain at timepoint $t ; l$ is boundary $x$ - coordinate of computational domain.

Technique of substitution can be applied to solve the problem of identification $k_{c}$ with the use of model (1). It's based on solving of series of direct problems through varying of hydraulic conductivity of particular zones of dam fill and foundation (see example in [16]). Numerical solution of the direct problem can be found by using implicit approach of finite difference method (FDM).

For this purpose partition of the seepage domain using a fine grid is conducted followed by piecewise line approximation of function representing piezometric heads in grid nodes. The series of direct problems for different dam sections are solved. Hydraulic conductivity simulation is performed until difference between computed and observed piezometric levels will exceed desired accuracy value.

Sufficient frequency of piezometric measurements providing with automated monitoring systems (daily or even hourly measurements) enables solving the problem of hydraulic conductivity identification. For steady gradually varied seepage flow described by Darcy equation hydraulic conductivity identification can be performed as follows.

Piezometer responds to headwater changes with a delay (time lag). It's assumed that response delay time depends on average seepage velocity within dam body section from entrance point to the corresponding reference piezometer where hydraulic conductivity is controlled. It was suggested that time lag $t_{L}$ approximately equals to travel time seepage flow needs to cover the distance $\Delta S$ along the stream line from entrance to the piezometer location. Then hydraulic conductivity of soil within that domain can be expressed as:

$$
k_{\mathrm{c}}=\frac{\Delta S^{2} \cdot t_{L}}{\Delta H},
$$

where $\Delta H$ is difference (drop) between headwater in reservoir and piezometer water level.

Based on observational data of reservoir water and reference piezometer water levels cross-correlation function was plotted (See fig. 2). Lag value is taken to be equal to timespan until piezometer level response initiated by headwater changing is finally stabilized [19]. It should be noted that degree of correlation between headwater and piezometric level may depend both on test sample size and behavior of reservoir water level for instance rising or lowering (corresponding to reservoir 
refilling and drawdown). Accuracy of time lag evaluation depends on measurements frequency significantly too. The higher frequency is the better.

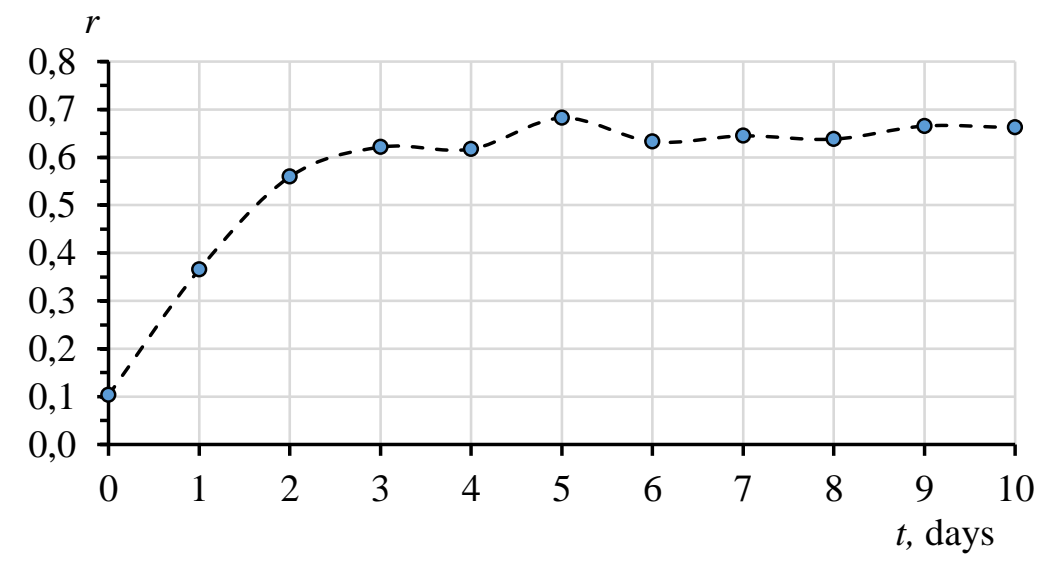

Fig. 2 - An example of cross-correlation function between reservoir and piezometer levels

Taking into account headwater behavior and other factors that determine distinctive features of seepage process and lag effects as well gives an interval estimation of average hydraulic conductivity within seepage domain. In the case studied simulation modelling resulted in average hydraulic conductivity values within the examined dam section along control piezometric line ranging from 8,5 to $14,7 \mathrm{~m}$ per day depending on reservoir behaviour. Largely results of identification of hydraulic conductivity of the dam section are consistent with design value of dam fill hydraulic conductivity $8,6 \mathrm{~m}$ per day adopted in the dam design project.

\subsubsection{Computational model identification}

Guiding by a priori knowledge about both dam design and operation particularities to solve the problem of system structural identification the set of "candidate models" [23] was selected. Such model set is used to choose from it the most probable actual model corresponding to monitoring data. Different hydraulic seepage schemes of the dam were considered as candidate models [14].

Computational seepage model calibration was performed by simulating (varying) of the ratio of hydraulic conductivities of the strata having different permeability by reference to already identified hydraulic conductivity of the dam fill. As foundation is stratified averaged hydraulic conductivity for several similar type soil layers for instance for several sandy layers was assigned.

Given uncertainty in regards to current condition of seepage control and drainage features different scenarios of facilities operability are considered in simulation modelling such as cases of proper operability of those features (like seepage computational model of dam equipped with drainage ditch) and their non-operability (like seepage computational model of dam with no drainage).

Sensitivity analysis was conducted to test effects of other features that can be present in the dam. As a result, several computational hydraulic type "candidate models" [2] were selected. Those are seepage schemes with different types of 
seepage control features (upstream blanket, inclined upstream core, grout curtain) and drainage features (sloped drainage, drain ditch and no drainage). It was assumed that steep phreatic line drop within upstream shoulder, that similar to effect of conventional impervious upstream core and upstream blanket, can also be caused by clogging of upstream sections of dam body and foundation as well as by deposition of silts over the upstream facing and on the bottom near the dam heel. Such deposits are often observed on earthen dams under long-term operation when providing diver inspections.

Simulation modelling representing different seepage computational situations was performed by means of finite element based software RocScience 6.037. Since seepage plane mapping (fig. 1) demonstrates spatial flow pattern to provide applicability of 2-D analysis a section view along the control piezometric line was constructed. Selected control line (polygonal chain 1-1 in fig. 1) goes through as many piezometers in the instrumented cross section as possible.

With the use of simulation modelling it was revealed that seepage computational model that incorporates homogenous earthen dam body resting on pervious foundation (of limited thickness) having upstream inclined core and short upstream blanket and with no drainage reproduces most accurately measured seepage performance (i.e. phreatic line position) in the cross section considered. So that seepage computational model can be identified as the most realistic one. In general, observed seepage regime can be identified as allowable one since it refers to one of the adopted seepage schemes of earth dam.

Varying of seepage computational models (as a means of sensitivity studies) provided useful insights in regards of each structure element effect on seepage performance. Thus was determined that either proper or poor operability of grout curtain hasn't significant influence on phreatic line position in dam downstream shoulder. On the contrary, drainage system operability affects the most phreatic surface position within dam toe where seepage waters emerging on the slope is being observed.

Consequently the hypothesis of poor efficiency of the existing drainage system (toe drain with ditch) was proved and hence insufficient dam draining was concluded. It was found out in computational model sensitivity analysis in regards of drainage parameters that $2.0 \mathrm{~m}$ deep drain ditch effects in sufficient phreatic line lowering within toe zone and thus providing allowable seepage regime and normal dam condition.

\section{Conclusions}

The problem of seepage regime identification in earthen dam was considered. The solution of the problem based on visual and instrumental observations in terms of data ambiguity and uncertainity regarding either dam condition, soils permeability or seepage control and drainage features operability both in dam body and foundation is proposed. Decomposing of the problem of seepage computational model identification was performed following by several separated problems solving sequentially: the problem of operational particularities identification and the problem of system's structure and parameters identification.

While investigating, the seepage computational model was understood as some simplification or generalized conceptualization of hydraulic type seepage scheme representing particularities of seepage performance of the dam. Hydraulic type 
seepage scheme usually incorporates soils' permeability characteristics of dam body and foundation as well as seepage control and drainage features presence that, when taken all together, determine dam seepage performance. It was assumed real seepage computational model may be not equivalent to that one foreseen in the project due to real soils' permeability characteristics that are always uncertain and ambiguous initially and because of different processes in the dam body, foundation and other structure elements developing during dam operation.

The technique of identification of dam fill hydraulic conductivity was presented based on correlation analysis of piezometric readings. Contour maps of groundwater levels were examined as well as simulation modelling was conducted with the purpose to determine the most probable seepage computational model reproducing measured seepage performance.

It was proved that identified seepage regime by reference to current condition of seepage control and drainage features meets general allowability criteria. Poor efficiency of existing drainage system (that includes toe drain and ditch) was determined as the main cause of adverse effects within dam downstream shoulder.

\section{REFERENCES}

1. Гольдин А.Л., Рассказов Л.Н. Проектирование грунтовых плотин. Москва: Энергоатомиздат, 1987. $304 \mathrm{c.}$

2. Аравин В.И., Носова О.Н. Натурные исследования фильтрации (теоретические основы). Ленинград: Энергия, 1969. 258 с.

3. Dam failures - statistical analysis. Bull. No. 99. Int. Commission on Large Dams (ICOLD). Paris. 73 p.

4. Zhang L.M., Xu Y., Jia J.S. Analysis of earth dam failures - A database approach First International Symposium on Geotechnical Safety \& Risk. Oct. 18-19, 2007 Shanghai, Tongji University, China. p. 293-302. URL: http://citeseerx. ist.psu.edu/viewdoc/download? doi=10.1.1.665.5064\&rep=rep1\&type $=$ pdf

5. Evaluation and Monitoring of Seepage and Internal Erosion: Interagency Committee on Dam Safety (ICODS)/ FEMAP-1032 / May 2015 / Fed. Emergency Management Agency. 576 p. URL: https://www.fema.gov/media-library-data/1436889238781-1b63946bfcb27 bab5d85f7f95a66ce35/FEMAP1032.pdf

6. Transactions of the 19-th Int. Congress on Large Dams. Vol. 3, Q. 74. 26-30 May. Florence-Italy. 1997.

7. Векслер А.Б., Ивашинцов Д.А., Стефанишин Д.В. Надежность, социальная и экологическая безопасность гидротехнических объектов: оценка риска и принятие решений. С.-Петербург : ВНИИГ им. Б.Е. Веденеева. 2002. 591 с.

8. Малаханов В.В. Техническая диагностика грунтовых плотин. Москва: Энергоатомиздат, 1990. $120 \mathrm{c.}$

9. Чугаев Р.Р. Гидротехнические сооружения. Ч.1. Глухие плотины. Москва: Агропромиздат, $1985.318 \mathrm{c}$.

10. Goubet A. Risques associés aux barrages. La Houille Blanche. 1979. N. 8. P.P. 475-490. 11. Аравин В.И., Нумеров С.Н. Теория движения жидкостей и газов в недеформируемой пористой среде. Москва : Гостехиздат, 1953. 616 с.

12. Полубаринова-Кочина П.Я. Теория движения грунтовых вод. Москва: Наука, 1977. $664 \mathrm{c}$.

13. Гладкий А.В., Ляшко И.И., Мистецкий Г.Е. Алгоритмизация и численный расчет фильтрационных схем. Киев : «Вища школа», 1981. 288 с.

14. Стефанишин Д.В. К оценке эксплуатационной надежности грунтовых плотин. Гидротехническое строительство. 1993. №8. С. 25-32. 
15. Ивашинцов Д.А., Соколов А.С., Шульман С.Г., Юделевич А.М. Параметрическая идентификация расчетных моделей гидротехнических сооружений. С.-Петербург: ВНИИГ им. Б. Е. Веденеева, 2001. 432 с.

16. Король В.В., Стефанишин Д.В. Параметрична ідентифікація математичних моделей процесів в гідротехнічних спорудах. Математичне та комп'ютерне моделювання. 3б. наук. пращь. Кам'янець-Подільський національний університет, Інститут кібернетики імені В.М. Глушкова НАН України; [редкол.: А. Ф. Верлань (відп. ред.) та ін.]. К.-Подільський: К.-Подільський національний університет, 2008. Вип. 1. С. 100-109.

17. Стефанишин Д.В. Про один підхід до оцінки стану земляної греблі, що перебуває в постійній експлуатації, за даними регулярних п'єзометричних спостережень. Гідроенергетика Украӥни. № 3. 2012. С. 27-32.

18. Jung In-Soo, Berges M., Garrett J.H.Jr, Kelly Ch.J. Interpreting the Dynamics of Embankment Dams through a Time-Series Analysis of Piezometer Data Using a NonParametric Spectral Estimation Method. Computing in Civil Engineering. 2013. P.P. 25-32. 19. Стефанишин Д.В., Дем'янюк А.В. Обгрунтування базової діагностичної моделі для контролю й прогнозування фільтрації в тілі земляної греблі за даними регулярних п'єзометричних спостережень. Екологічна безпека та природокористування. 3б. наук. пращь. Вип. 24 (№ 3-4). Київ: ІТГІП НАНУ, КНУБА, 2017. С. 138-147.

20. Ageing of dams and appurtenant works. Int. Commission on Large Dams (ICOLD). Committee on ageing of dams. Cairo, November, 1993.

21. Design Standards No. 13. Embankment Dams DS-13(8)-4.1: Phase 4 (Final) Jan. 2014 Chapter 8: Seepage. URL: https://www.usbr.gov/tsc/techreferences/ designstandardsdatacollectionguides/finalds-pdfs/DS13-8.pdf

22. Тихонов А.Н., Арсенин В.Я. Методы решения некорректных задач. Москва : Наука, $1979.285 \mathrm{c}$.

23. Льюнг Л. Идентификация систем. Москва: Наука, 1991. 431 с.

\section{REFERENCES (TRANSLATED AND TRANSLITERATED)}

1. Goldin, A. L., Rasskazov, L. N. (2001). Design of earth dams. Moscow, Energoatomizdat, 304 p. (in Russian).

2. Aravin, V. I., Nosova, O. N. (1969). Field Studies of Seepage (Theoretical Fundamentals). Leningrad, Energiya, 258 p. (in Russian).

3. Dam failures - statistical analysis. Bull. No. 99. Int. Commission on Large Dams (ICOLD). Paris. 73 p.

4. Zhang, L. M., Xu, Y., Jia, J. S. (2007). Analysis of earth dam failures - A database approach First International Symposium on Geotechnical Safety \& Risk. Shanghai, Tongji University, China, 293-302. Retrieved from http://citeseerx.ist. psu.edu/viewdoc/download? doi=10.1.1.665.5064\&rep=rep1\&type=pdf

5. Evaluation and Monitoring of Seepage and Internal Erosion: Interagency Committee on Dam Safety (ICODS)/ (2015). FEMA P-1032. Federal Emergency Management Agency. Retrieved from https://www.fema.gov/media-library-data/1436889238781-1b63946bfcb27 bab5d85f7f95a66ce35/FEMAP1032.pdf.

6. Transactions of the 19-th Int. Congress on Large Dams. (1997). Vol. 3, Q. 74. FlorenceItaly.

7. Veksler, A. B., Ivashintsov, D. A., Stefanishin, D. V. (2002). Reliability, social environmental safety of hydraulic structures: risk assessment and decision making. S.Pb, VNIIG named after B.E. Vedeneev, 591 p. (in Russian).

8. Malahanov, V. V. (1990). Technical diagnostics of earth dams. Moscow: Energopromizdat, 120 p. (in Russian).

9. Chugaev, R. R. (1985) Hydraulic structures. Part 1. Non-overflow dams. Moscow, Agropomizdat, 318 p. (in Russian). 
10. Goubet A. (1979). Risques associés aux barrages. La Houille Blanche. N. 8, 475-490.

11. Aravin, V. I., Numerov, S. N. (1953). Theory of motion of liquids and gases in a nondeforming porous medium. Moscow, Gostechizdat, 616 p. (in Russian).

12. Polubarinova-Kochina, P. Ya. (1977). Theory of Ground Water Movement. Moscow, Nauka, 664 p. (in Russian).

13. Gladkiy, A. V., Lyashko, I. I., Mistetskiy, G. E. (1981). Algorithmization and Numeric Calculation of Filtration Schemes, Vyscha Shkola, Kyiv, 288 p. (in Russian).

14. Stefanyshyn, D. V. (1993). Assessing the operational reliability of earth dams. Hydrotechnical Construction. №8, 25-32. (in Russian).

15. Ivashinsov, D. A., Sokolov, A. S., Shulman, S. G., Yudelevich, A. M. (2001). Parametric identification of hydraulic structurel design models. S.Pb, VNIIG named after B. E. Vedeneev, 432 p. (in Russian).

16. Korol, V. V., Stefanyshyn, D. V. (2008). Parametric identification problems of mathematical models of hydraulic structures. Mathematical and numerical modeling. Issue 1, 100-109. (in Ukrainian).

17. Stefanyshyn, D. V. (2012). About an approach to assess of technique at earth dam in permanent operation according to data of regular piezometric observations. Hydroenergy of Ukraine, № 3, 27-32. (in Ukrainian).

18. Jung In-Soo, Berges, M., Garrett, J.H.Jr, Kelly, Ch.J. (2013). Interpreting the Dynamics of Embankment Dams through a Time-Series Analysis of Piezometer Data Using a NonParametric Spectral Estimation Method. Computing in Civil Engineering. 25-32.

19. Stefanyshyn, D. V., Demianiuk, A. V. (2017). Justification basic diagnostic model for control and forecast seepage through earthfill dams according to regular piezometric observations. Environmental safety and natural resources, №24 (№ 3-4), 138-147. (in Ukrainian).

20. Ageing of dams and appurtenant works. (1993). Int. Commission on Large Dams (ICOLD). Committee on ageing of dams. Cairo.

21. Design Standards No. 13 Embankment Dams DS-13(8)-4.1: Phase 4 (Final). (2014).

Chapter 8: Seepage. Retrieved from https://www.usbr.gov/tsc/ techreferences/ designstandards-datacollectionguides/finalds-pdfs/DS13-8.pdf

22. Tikhonov, A. N., Arsenin, V. Y. (1979). Methods of solving of ill-posed problems. Moscow: Nauka, 285 p.

23. Ljung, Lennart. (1987). System identification: Theory for the user. Prentice-Hall, Inc, $255 \mathrm{p}$.

The article was received 22.03.2019 and was accepted after revision 09.04.2019

\section{А.В. Дем'янюк, Д.В. Стефанишин ІДЕНТИФІКАЦІЯ РЕЖИМУ ФІЛЬТРАЦІЇ НА ЗЕМЛЯНІЙ ГРЕБЛІ В УМОВАХ НЕПОВНОТИ ДАНИХ}

Анотація. Розглянуто один випадок ідентифікації режиму фільтрації на земляній греблі. Рішення базується на даних візуальних та інструментальних спостережень 3 урахуванням неоднозначності та невизначеності інформації про стан греблі, щодо проникності грунтів, працездатності протифільтраційних та дренажних пристроїв у тілі дамби та в їі основі. Запропоновано методику визначення значення коефіцієнта фільтрації грунту тіла земляної греблі на основі кореляційного аналізу даних п’єзометричних спостережень. Для спрощення задачі ідентифікації режиму фільтрації досліджено планову картину рівнів підземних вод в тілі греблі. Здійснено імітаційне моделювання для визначення найбільш вірогідної фільтраційної схеми греблі, що найкращим чином відповідає натурним даним. Особлива увага приділялася врахуванню роботи протифільтраційних і дренажних пристроїв. Було підтверджено, що режим фільтрації на земляній греблі відповідає критеріям допустимості. 
Ключові слова: неоднозначність і невизначеність; дані спостережень; земляна гребля; ідентифікація; недосконала інформація; фільтрація; режим фільтрації; розрахункова модель фільтрації; імітаційне моделювання

\section{Дем'янюк Алла Володимирівна}

старший викладач кафедри гідротехнічного будівництва та гідравліки Національного університету водного господарства та природокористування (НУВГП)

Адреса робоча: 33028 Україна, м. Рівне, вул. Соборна, 11

\section{Стефанишин Дмитро Володимирович}

доктор технічних наук, провідний науковий співробітник Інституту телекомунікацій і глобального інформаційного простору НАНУ, професор кафедри гідротехнічного будівництва та гідравліки Національного університету водного господарства та природокористування (НУВГП)

Адреса робоча: 33028 Україна, м. Рівне, вул. Соборна, 11

e-mail: d.v.stefanyshyn@nuwm.edu.ua

ORCID: https://orcid.org/0000-0002-7620-1613 